$\underline{\mathbf{P}-198}$

\title{
Xanthine Oxidase Inhibitory Activity of Selected Chalcone Derivatives
}

\author{
Khairana Husain ${ }^{1, *}$, Lam Kok Wai ${ }^{1}$, Fadzureena Jamaluddin ${ }^{2}$, Jamia Azdina Jamal ${ }^{1}$ and Nurnajmul \\ Ummah $\mathrm{Abu}^{1}$ \\ ${ }^{I}$ Drug and Herbal Research Centre, Faculty of Pharmacy, Universiti Kebangsaan Malaysia, Jalan Raja Muda Abdul \\ Aziz, 50300 Kuala Lumpur; ${ }^{2}$ Natural Products Division, Forest Research Institute Malaysia,52109 Kepong, Selangor; \\ E-mail: khairana@pharmacy.ukm.my
}

Xanthine oxidase (XO) is a key molybdoflavoprotein enzyme that functions in catalysing the oxidation of hypoxanthine and xanthine to uric acid. Excessive uric acid will results in hyperuricaemia which is the crucial cause of gout. In the present study, a series of thirty-five of chalcone derivatives were evaluated for inhibitory activity against xanthine oxidase in vitro. From the study, seventeen compounds (47.2\%) exhibited XO inhibitory activity at $200 \mu \mathrm{g} / \mathrm{mL}$ which only four compounds $(0.1 \%)$ inhibited XO activity at more than 50\%. Compound 14, 1,3-bis(4-hydroxyphenyl)prop-2-en-1-one, showed the strongest activity more than $50 \%$ at $20 \mu \mathrm{g} / \mathrm{mL}$ with $\mathrm{IC}_{50}$ values of $15.31 \mu \mathrm{g} / \mathrm{mL}$ as compared to positive control of allopurinol (IC S $_{50}$ $=12.86 \mu \mathrm{g} / \mathrm{mL}$ ). The results suggest that compounds 14 can be further investigated to be developed into a XO inhibitor.

Keywords: Chalcone, Xanthine oxidase, Inhibitor. 